\title{
Cultural Reflections on the Modernization of State Administration
}

\author{
Jian-Chun ZHAO \\ (College of Marxism, North China Electric Power University, Baoding, Hebei 071003, China) \\ zhaojianchun2222@126.com
}

Key words: Modernization, Advanced culture, Modernization of state governance, The core values of Chinese socialism, Run the Party strictly.

\begin{abstract}
In the new period, as an important part of the strategy of comprehensively and strictly administering the party, the modernization of state governance is characterized by learning and emphasis. To ensure that the "national governance modernization" truly implemented, we must seize this "key minority cadres, only to let them play the vanguard in the practice of national governance modernization in the whole process of the role, in order to fully call" ordinary majority "follow up in the whole process of Party construction. At the same time, only the style of leading cadres of the problem has been improved, they are "the modernization of national governance" in the execution was recognized, results in order to protect the national governance modernization practice overall. Culture is the precursor of action, and scientific culture can guide scientific practice. As the cultural system, the four main cultures of Pyramid, namely, non culture, standard culture, moral culture and belief culture, are the four main points for training and refining the scientific right of leading cadres. Starting from the training and tempering of these four cultures, this article will study the scientific right of leading cadres.
\end{abstract}

\section{Introduction}

In the new period of deepening the "comprehensive and strict party management" strategy, the whole Party has launched a review of "modernization of state governance". This is an important part of the strategy of comprehensively administering the party strictly. Then, how can we ensure that the modernization of national governance is implemented? The key is to seize the "key minority" of leading cadres. They are the vanguard of the practice of "modernization of national governance". Only when the style of leading cadres is obviously improved, their executive power in the modernization of national governance has been clearly recognized, can we guarantee the effect and achievements of the overall practice of "modernization of national governance". So how do we play the key role of "key minority" in the modernization of national governance? As we all know, culture is the precursor of action. Only scientific cultural system can guarantee the tension of thought, and then lead to the success of practice. There are many cultures, but in all cultures, "non culture, formal culture, moral culture, belief culture" constitute the main frame of the cultural system of Pyramid. In the framework of Pyramid, each culture plays different roles, but it covers each other and presents a progressive relationship at the same time. Of these four cultures, "non culture" is the basis, the "rule culture" and "moral culture" are the protection, and "belief culture" is the driving force. This article will begin with the cultivation and tempering of the four leading cadres, and study the scientific rights of leading cadres.

\section{Right and Wrong Culture}

What is "non culture"? In short, the sense of "right" and "wrong" is also called "non consciousness"'". Human beings have gradually formed the criterion of "yes" and "no" in the practical life of the last ten thousand years. Influenced by the Chinese civilization for thousands of years, the Chinese people's "non culture" also exudes a strong Chinese flavor, "The book of Rites" words "ritual, so close, never suspected, to do with the difference, that is." ${ }^{1}$ In traditional Chinese cognition, "non consciousness" is regarded as "the Tao of the day", and "the meaning of the land" is also known to the people" ${ }^{2}$ Since the founding of the Communist Party of China, the leaders of all 
previous party have always regarded "non consciousness" as an important starting point of Party building work. Mao Zedong in "on the ten major relationships" has stressed "party to distinguish right and wrong", Deng Xiaoping on "non culture" in the party building also pointed out that "the party should distinguish between theories and line, to carry out criticism and self-criticism, mutual help, mutual supervision, to overcome all wrong ideas." ${ }^{3} \mathrm{Xi}$ Jinping in the party's mass line of educational practice summary of the meeting also stressed that "the party to carry out positive ideological struggle, help the majority of Party members and cadres to distinguish right from wrong, to distinguish between true and false, uphold the truth, correct mistakes, and enhance solidarity and unity of will." 4

However, in real life there are some of the leading cadres is non consciousness, even confuse right and wrong behavior. First of all, the expression of "Lord" and "servant" is the question of "yes" and "non". The purpose of the Communist Party of China is to serve the people wholeheartedly, that is to say, cadres are servants rather than masters". But some of the leading cadres of the confusion of the source of power, power, power to master the problem of whom to serve, in practice, indifferent to the voice of the ordinary Party members and the interests of the masses, the wrong stick to the idea of "official standard", people see themselves as superior, "master", carrying out privilege behavior, serious damage the party's image; secondly, to "party spirit" and "the people" on the issue and. Some cadres mistake the interests of the party and the interests of the people, and think that party spirit is not "people"'". Seriously hurt the feelings between the party and the masses. Once again, in the achievements of the problem is and non. Some leading cadres only pursue their personal career in the first place, ignore the long-term interests of the people, and the wrong concept of achievements will inevitably create a group of "image project" and "Jerry built project"".

In the context of "modernization of state governance", how can we correct the wrong "non culture"? This is crucial for the whole party, especially for the "key minority".

First of all, to put the master servant relationship. Leading cadres should correct the concept of "privilege" of the "official", and understand that all their powers are given by the broad masses of the people. The leading cadres can only represent the people, not offside, instead of the people. At the same time, we should also understand that power is used to serve the broad masses of the people, and that power can not be regarded as a product of the distribution of higher authorities, nor can it be regarded as a product of individual struggle, nor can it be used for personal gain. Otherwise, it is possible to generate privileged ideas and privileges. Leading cadres should oppose the idea of privilege, and must abandon the idea and understanding of power and identity, status, especially super welfare treatment" ${ }^{5}$ Comrade Xi Jinping put forward the specific requirements of the three strict three real, which "discipline" is the leading cadres must deal with the masses of the people "and" relationship, considering all the problems are always put the interests of the people in the first place, flooding will not allow privilege thought.

Secondly, the relationship between "party spirit" and "people's nature" should be put right. At the National Conference on propaganda and ideological work, general secretary Xi Jinping talked about the logical relationship between party spirit and the people, and emphasized the unity of "party spirit" and "people's nature". This unity is embodied in two aspects: first, the fundamental interests of the party and the people are highly consistent. The Communist Party is the leading force in the cause of socialism with Chinese Chinese characteristics; it represents the fundamental interests of the overwhelming majority of the people and serves China. In addition, the party does not exist the special interests of their own; in addition, the party and the masses the goal is highly consistent. The Communist Party of China's goal of "building a well-off society in an all-round way", "the two one hundred years" and "the Chinese dream of the great rejuvenation of the Chinese nation" are all aimed at the interests of the broad masses of the people. So, we can think of "adhere to the spirit is to adhere to the people, adhere to the people of that party, resides in the people's Party of, not from the people of the party, people are not out of the party." 6

Thirdly, we should deal with the relationship between the realization of the self value of the leading cadres and the interests of the masses. Values are propositions and opinions about what is 
value, how to create value, and how to judge value. For leading cadres, whether the values are correct or not directly determines the leaders' pursuit goals, spiritual motivation and spiritual support, and determines the direction and manner of the right to use. At present, in the background of "the modernization of national governance", leading cadres should be guided by the socialism core values, uphold the values of patriotism, dedication, integrity, kindness, to realize their own value in the process, and for the benefit of the people, to do practical things for the masses of the people, to create the test the people and the times of performance.

\section{Discipline Culture}

What is a custom culture? In short, it means obedience to certain principles, practices, or rules. Since ancient times, the Chinese people are known for their "custom of tradition". Since the founding of the Communist Party of China, strict discipline has been laid down on its programmed and the party constitution. In the early days of reform and opening up, Deng Xiaoping pointed out: "to uphold and improve the leadership of the party, we must strictly uphold Party discipline and greatly strengthen discipline."." ${ }^{7}$ General secretary Xi Jinping at the five plenary session of the eighteen Central Commission for Discipline Inspection, also stressed the need to strict political discipline and political regulations, requiring discipline, discipline, in a more important position.

However, in real life, there are some leading cadres who do not have good rules and regulations, and even behave in a wrong way and behave in a wrong way. First, there is a lack of reverence for Party discipline. Some leading cadres of the general public power to seek private gain, contact some business circle "friend", the "official zouxue" phenomenon It is often seen. There are a few leading cadres abusing public power, cronyism, yuminzhengli, despise the people, in the name of all kinds of public funds extravagance and waste. In the process of cadre examination and appointment, go through the motions and conceal important information. Thus, integrity and scientific concept of governing for the people with the right to say it, write on paper, is not put into practical action; secondly, for the lack of respect for the law of heart. Some leading cadres of the concept of the rule of law indifferent, in accordance with the law is not strong, the phenomenon of corruption have occurred in a high-pressure situation against corruption, the convergence does not close hand, instead of once again become aggravated; the lack of inclusive social supervision. Some of the leading cadres of the supervision of the people and social media as a constraint on its own power, feel as "not free", in addition to the influence of privilege, not a correct understanding of the power and the necessity of the importance of supervision is one of the important factors. There are very few leading cadres in the formulation and implementation of major decisions, the expert opinions and media questioning as a barrier to use rights.

In the background of "the modernization of national governance", how to build a cadre of rules consciousness? This is essential for us to push forward the modernization of national governance in an all-round way.

First of all, Party members and cadres should be shaped to fear the party's political rules. To make the key a few remain very careful, with profound respect and humility attitude, adhere to prudent use right. Leading cadres to do with the right care, is to achieve the right to use "hand shaking" spirit, we should do the power in charge of the masses of the people, will often think of greed and selfishness of the scourge, must be cautious, careful, cautious, careful early, carefully turn right, we should do self-discipline, self-respect, self-examination, self excitation etc.. No matter at any time can not hold the "power in hand, obsolete," the wrong idea, must not make the power of the hands of commercialization and vulgarization. Otherwise, it may be all kinds of unexpected "sugar coated bullet" to "ice" and "abyss" boundary layer.

Secondly, we should cultivate party members and cadres to respect the state laws. The compliance with laws and regulations, strengthen the rule of law culture, in strict accordance with the right. In the fourth Plenary Session of the 18th CPC Central Committee, the party will build a socialist legal system with Chinese characteristics and a socialist country ruled by law as a general objective and general requirement for deepening reform in a comprehensive way. As for leading cadres of the party, we must meet the practical requirements of building a socialist country under 
the rule of law, adhere to the rule of law in accordance with the law, use power according to law, adhere to law enforcement for the people, and make the power in the hands subject to legal restrictions. To improve the party members and cadres' rule of law culture and the ability to handle affairs according to law, we should gradually try to assess the effectiveness of the rule of law and the ability to act in accordance with the law as a key indicator of the performance of leading cadres. Comprehensive strictly under the background of leading cadres should realize the power must be within the scope of laws and regulations in the operation of the "limited power", regulate the use of the hands in accordance with the relevant provisions of the law of power, can never let any power beyond the law, there can be no special citizens above the law. "'. Only when leading cadres use the power in accordance with the law can we guarantee the political performance of satisfying the general public. Therefore, the leading cadres should seriously learn legal knowledge, strengthen the rule of law, to be a model study of law, law, law, law enforcement, regulate the use of the power system, and program. According to the individual leading cadres of dereliction of duty, breach of privilege, Zhifafanfa even favoritism and other violations of law, can not only rely on the moral education must be given legal punishment, law enforcement role play. Only in strict accordance with the rights, in order to prevent those who override the Constitution and the law, beyond the Constitution and the law outside the "special citizen", in order to prevent the occurrence of violations, and ensure the operation of power conservation, boundary constraint, safeguard the people's power to service the people, the power of the people by the people to give. At the same time, in order to ensure that leading cadres use the power according to law, they should strengthen effective legal supervision over their powers and actions so that leading cadres can effectively exercise the power conferred by the people in accordance with the provisions of the law.

Thirdly, we should guide the "key minority" to form a tolerant attitude towards social supervision. We should actively accept and correctly supervise all aspects of the work and achieve the right to bask in the sun. To adapt to and accept supervision from all sides is the necessary requirement of scientific right of leading cadres under the condition of full and strict party management. Therefore, on the one hand, leading cadres should be accustomed to the use of power in the situation of supervision and restriction. Some leading cadres of the party's eighteen since the supervision of all aspects of society and the relevant departments of the state inspectors showed very inappropriate, the official does not talk to students' emotion. This phenomenon shows that individual leading cadres have adapted to the "right to do whatever they like" right, and they have not correctly realized that power should be accepted by the supervisory authority. On the other hand, to accept supervision, there should be modest quality, generous mentality. Some leading cadres accept criticism on the surface, but in fact they regard the criticism of the masses as trouble for themselves. At present, countries in all aspects of social public opinion supervision department, people's supervision and continuously advancing period, leading cadres should follow public opinion, supervision as a unique prevention and protection, often self-respect, self-examination, self motivation, finding and correcting errors in the right time. In practical work, leading cadres should be able to bask in the sun, that is, the scope of their powers, responsibilities, limits of power, procedures and other rights announced to the public, for all aspects of supervision to facilitate conditions. Only in this way can we make ourselves less mistakes or make no mistakes under the conditions of today's comprehensive and strict party management, and really make a solid performance.

\section{Moral Culture}

Since ancient times, Chinese known as "governing by Morality" tradition, moral influence, advocating virtue. In 1956, comrade Mao Zedong in the opening speech of the Communist Party of China "eight" had stressed that "in the midst of many of our comrades, there are still some violation of Marx's viewpoint and style - - - - - must strengthen the party's ideological education, to overcome our ranks of these serious shortcomings." 8 "Observing communist morality", which was written into the party constitution at this conference, has become the norm and obligation of every Communist Party member. Deng Xiaoping also believes that "correct party conduct" is the key to 
correct the social atmosphere." ${ }^{9}$ In the early stage of reform and opening up, he was warning the party attached great importance to moral consciousness, he pointed out: "since we adopted the opening up and enliven the two aspects of economic policy of more than one or two years, a number of cadres have been eroded....... The wind is very strong. If our party is not serious, not firmly stop it, then, our party and country did happen will "change the face" problem. This is not alarmist talk." ${ }^{10}$ In May 2014, when Xi Jinping visits in Henan stressed that party members and cadres, especially leading cadres, must strengthen moral cultivation as a compulsory course of life is very important, with strict standards to strengthen self-discipline, accept his moral strength to strive to win the hearts and win achievements"11

However, in real life, there are some leading cadres whose moral consciousness is not strong, which is contrary to moral ethics and trampling on moral bottom line. They were eroded by money worship, hedonism, and extreme individualism, and their moral consciousness slipped, often touching the moral red line". This will inevitably damage the image of the party and the government in the minds of the ordinary people, and it can not guarantee the rights and interests of the masses. Moral consciousness is the basic bottom line of an official, and without the basic moral consciousness and the concept of conscience, it is impossible to speak of "party spirit" and "advanced nature".

In the context of "modernization of state governance", how can we further enhance the moral consciousness of Party members and cadres? This is a question we should make great efforts to solve in the one hundred years since the founding of our party.

First of all, Party members and cadres should strive to improve their moral cultivation. In the overall environment of strict party management, leading cadres own noble moral behavior is an important guarantee for the scientific right to use, is the so-called "political" to Germany, such as Beichen, its home, and the stars arch."12 For the leading cadres, should be moral, ethical and the sense of shame. Through self-examination, self-discipline, self denial and other ways to enhance personal accomplishment, temper their morals, in practice to do for the people, pragmatic and honest. In the comprehensive deepening reform of the moment, faced with the task of leading cadres than ever so arduous, requires leading cadres adhere to the concept of governing for the people, strengthen the ability to learn about principles in the exchanges, maintain the fine style of plain living in life; secondly, the leading cadres in the use of power, always with politics the original intention and correct political position to remind myself, with the idea of moral restraint and caution oneself, overcome deep inside some "does not matter" luck, do not violate the moral and conscience, things do not take, do not ill-gotten gains against the interests of the masses of things; thirdly, Party cadres should continue to strengthen "power is the responsibility, leadership is service, the cadre is the director" ${ }^{13}$ The sense of responsibility, thereby enhancing the sense of commitment and moral care, and providing important guarantee for leading cadres to adhere to professional ethics. In the current materialistic society, leading cadres are in possession of certain powers. In the face of temptation, they should always be "gentlemen", "check" and "if ever"'"14 Attitude, check yourself in the right is about the rules, whether to speak decent, do pay in exchanges. In order not to be immoral people dragged into the water, or to withstand temptation as "sliding down", we must adhere to the moral cultivation, education, self evaluation and supervision to promote SHUTER de Masanori finally, in the "big background; the modernization of national governance", it is necessary to pay attention to the cultivation of individual moral leadership cadres. At the same time, it will be treated as a group, in strengthening the individual moral consciousness of power at the same time, but also to strengthen the construction of community power of moral consciousness, eventually making the overall power of moral consciousness can be improved, and ultimately the formation of perfect virtue.

\section{Belief Culture}

What is faith culture? In short, it refers to the admiration and esteem of a certain idea, proposition, or doctrine, and serves as a guide and guide for action. Faith, as the most basic emotion of a human being, embodies the love for the soul. Augustin believes that faith is thought in favor." 15 
"FayuanZhulin" volume 94: "life without faith, he laughed out is constant." All this shows that human beings need faith, and we can strive to narrow the distance between reality and dreams by faith. Mao Zedong was severely criticized for a lack of belief in the cause of Party members and cadres, he believes that "a lot of people to work irresponsible, nianqingpazhong, and the heavy burden to others, pick their own light. Currently, first for his own plan, and then for others to...... The comrades and the people but not full of passion, desolate, indifferent, petrified. This kind of person is not really a communist, or at least a mere communist." ${ }^{16}$ Deng Xiaoping has also repeatedly expressed his endless belief in the cause of the party. He said fondly, "I am the son of the Chinese people, and I love my country and my people with deep love."." In the new period, the Communist Party of Xi Jinping, especially the key minority "put forward specific requirements, he stressed that" the Communists spiritual ideals and beliefs is the "calcium", there is no ideal and belief, ideal belief, spirit will "get calcium", "soft bone disease"."17

Nothing is more precious to a communist than a belief. Whether in the revolution period or in the period of peaceful construction, beliefs are based on the present for every member of the Communist Party, is to withstand any setbacks test of mental spine. Without the Marx doctrine, the cause of communism and the unswerving belief in the people, there would be no political soul to overcome all difficulties and realize the Communist ideals. However, some leading cadres are either lack of belief or confusion of belief. This will inevitably lead to some leading cadres, no firm political stance, ideals and beliefs shaken, problems will appear out of control without the principle of no discipline, and even help the spirits bless to seek psychological comfort, eliminate fear.

Under the background of "modernization of state governance", how to further strengthen the belief culture of Party members and cadres? This is our comprehensive deepening the reform process, the inexhaustible power to tackle tough.

First of all, we must further strengthen the faith of Marx doctrine. As a scientific, open and developing theoretical system, Marx doctrine is full of theoretical vitality and vitality. On the basis of the unity of science, revolution and practice, it finds and expounds the general law of human society development. The Marx doctrine, including not only the basic theory founded by Marx and Engels et al of the Marx doctrine, but also including China of the Marx doctrine, Mao Zedong thought and the theoretical system of socialism with China. The firm belief in Marx's doctrine is our ideological and theoretical weapon to overcome all difficulties, and is the magic weapon for the party to keep the advanced nature at all times. Second, we must further strengthen the faith in the cause of communism. This great undertaking is not only a process that conforms to the law of human social development, but also a process that conforms to the vision of a human being in pursuit of a better life, and is a unity of regularity and unity of purpose. As one of the most great cause of communism will be realized, but it should be pointed out that the realization of communism is a long history and is full of the arduous and tortuous process. At present, our country is still in the primary stage of socialism, this stage will continue for a long period of time, "China dream, to create all the people more wonderfull life, go15, we need everyone to pay the hard work and hard work." ${ }^{18}$ In the realization of communism in the long process, we only firm belief in communism to avoid detours, go astray; again, always firmly to the people of faith. The broad masses of the people have created the material wealth and spiritual wealth of human society, which determine the speed and direction of social change, and the history of human society has always been written by the masses. Is the so-called "people are the foundation of ancient" ${ }^{19}$ Since ancient times, the public attitude for or against the core factor influence, a political party, a regime of success or failure. On the one hand China Communist Party as the vanguard of the working class Chinese, on the other hand, as China people and the vanguard of the Chinese nation, the two vanguard nature determines the fundamental purpose of our party is serving the people wholeheartedly". In the period of revolution, it is the biggest political advantage of our party to keep close ties with the masses. During the period of peaceful construction, we should continue to give full play to this unique advantage and resolutely avoid the tendency to break away from the masses. To believe in the people, we must always have a sense of awe in the people, and under no circumstances do they harm or infringe upon the fundamental interests of the broad masses of the 
people. To believe in the people, we must fully carry out the tenet of serving the people wholeheartedly, and take good care of the vital interests of the broad masses of the people. To believe in the people, we must adhere to the working policy of "coming from the masses and going among the masses", and paying attention to the creativity of the people.

\section{Conclusion}

In the new period, as an important part of the strategy of comprehensively and strictly administering the party, the modernization of state governance is characterized by learning and emphasis. To ensure that the "national governance modernization" implemented, will be the key minority hold leading cadres, only to let them play the vanguard in the practice of national governance modernization in the whole process of the role, in order to fully call to "follow up most common" in the whole Party Construction process. At the same time, only the style of leading cadres of the problem has been improved, they are "the modernization of national governance" in the execution was recognized, results in order to protect the national governance modernization practice overall. Culture is the precursor of action, and scientific culture can guide scientific practice. As the cultural system, the four main cultures of Pyramid, namely, non culture, standard culture, moral culture and belief culture, are the four main points for training and refining the scientific right of leading cadres. For the leading cadres, the scientific use of right is the basis for constructing the correct "non culture", which requires them to "master" in "and" on the issue, "party spirit" and "the people" on the issue, political issue, always strictly distinguish the "yes" and "no" boundaries. Secondly, the scientific use of the protection of the right is to train and exercise the "rules of culture" and "moral culture", "cultural rules" requires leading cadres of the party gradually formed awe, reverence for the law of the heart, inclusive social supervision. "Moral culture" requires that party members and cadres should strive to improve their moral cultivation, but also always use moral concepts to restrain and warn themselves. At the same time, they should also enhance their sense of responsibility and moral care. Finally, the scientific use of the power source power from "establish faith culture", which requires leading cadres in the background of "national governance modernization", further firmly on the Marx doctrine of faith, to further strengthen the Communist cause of faith, always firmly to the people of faith. Only in the "national governance modernization" in training and exercise good "these four kinds of key minority, to support a stable culture system of Pyramid, and promote the comprehensive series of activities strictly implement.

\section{Acknowledgements}

This paper is supported by the Fundamental Research Funds for the Central Universities (Grant No. 2014MS185)("Study on the Enlightenment of new culture movement to cultural power"), the Humanities and social science research project of Hebei higher education institutions (Grant No. SZ151180)( "Study on the enlightenment movement of Beijing, Tianjin and Hebei in the period of the Republic of china").

\section{References}

[1] Liu Zehua. China political thought Shi Ji second volumes of the Qin Dynasty to the modern political theory [M]. Beijing: People's Publishing House.2008:40.

[2] Liu Zehua. China political thought of Shi Ji volume first [M]. history of pre Qin political thought Beijing: People's Publishing House.2008:90.

[3] Deng Xiaoping, Deng Xiaoping. Second volume, 1975-1982, Second Edition, [M]., Beijing: People's publishing house,.1994:148. 
[4] Xi Jinping.Speech at the concluding session of the party's mass line educational practice [M]. Beijing: People's publishing house,.2014:21.

[5] Ma Yonghao. Against the privilege of thinking must set up correct view of power of Party and government cadres [J]. journal, 2014,06:28.

[6] People's daily, Department of theoretical compilation. Deep understanding of the important speech of general secretary Xi Jinping [M].: People's publishing house,.2014:559.

[7] Selected works of Deng Xiaoping. Second volumes [M]., Second ed. Beijing: People's publishing house, 1994:271.

[8] Collected works of Mao Zedong. Seventh volume [M], Beijing: People's publishing house, 1999:116.

[9] The Central Committee of the Communist Party Literature Research Center. Deng Xiaoping thought chronicle 1975 1997[M]. Beijing: Central Literature Publishing House.1998:338.

[10]Deng Xiaoping, Deng Xiaoping. Second volume, 1975-1982, Second Edition, [M]., Beijing: People's publishing house,.1994:402.

[11]A speech from Xi Jinping's visit to Henan in May 10, 2014

[12]LvZhenyu. History of Chinese political thought [M]. Beijing: People's publishing house,.2008:75.

[13]Wang Sheng. Leading cadres should adhere to the morality of right to use [J]. leading science, 2012 (31): 31.

[14]Li Chengwu. Editor in chief.Moral leadership of officer in charge of ethics. [M]. Beijing: People's publishing house,.2012:45.

[15]Zhang Rong. The sacred call.Augustin's study of religious anthropology [M]. Shijiazhuang: Hebei Education Press,.1999:132.

[16]Mao Zedong, Mao Zedong. Second volume, [M]., Beijing: People's publishing house,.1991:660.

[17]"People's Daily" Department of theoretical compilation. In-depth study of Comrade Xi Jinping important discussion [M].: People's publishing house,.2013:2.

[18]Xi Jinping on governance [M]. Beijing: Foreign Language Press,.2014:41.

[19]Yang Zhengwu.People. Ben. People's livelihood.Democracy. [M]., Beijing: People's press,.2007:35. 